\title{
Cardiopulmonary Exercise Testing for Preoperative Evaluation: What Does the Future Hold?
}

\author{
James M. Otto ${ }^{1}$ - Denny Z. H. Levett ${ }^{2,3} \cdot$ Michael P. W. Grocott $^{2,3}$ \\ Published online: 3 February 2020 \\ (C) The Author(s) 2020
}

\begin{abstract}
Purpose of Review Cardiopulmonary exercise testing (CPET) informs the preoperative evaluation process by providing individualised risk profiles; guiding shared decision-making, comorbidity optimisation and preoperative exercise training; and informing perioperative patient management. This review summarises evidence on the role of CPET in preoperative evaluation and explores the role of novel and emerging CPET variables and alternative testing protocols that may improve the precision of preoperative evaluation in the future.

Recent Findings CPET provides a wealth of physiological data, and to date, much of this is underutilised clinically. For example, impaired chronotropic responses during and after CPET are simple to measure and in recent studies are predictive of both cardiac and noncardiac morbidity following surgery but are rarely reported. Exercise interventions are increasingly being used preoperatively, and endurance time derived from a high intensity constant work rate test should be considered as the most sensitive method of evaluating the response to training. Further research is required to identify the clinically meaningful difference in endurance time. Measuring efficiency may have utility, but this requires exploration in prospective studies.

Summary Further work is needed to define contemporaneous risk thresholds, to explore the role of other CPET variables in risk prediction, to better characterise CPET's role in combination with other tools in multifactorial risk stratification and increasingly to evaluate CPET's utility for preoperative exercise prescription in prehabilitation.
\end{abstract}

Keywords Cardiopulmonary exercise testing $\cdot \mathrm{CPET} \cdot$ Surgery $\cdot$ Exercise $\cdot$ Preoperative evaluation

This article is part of the Topical Collection on Preoperative Evaluation

James M. Otto

james.otto@uhs.nhs.uk

Denny Z. H. Levett

d.levett@soton.ac.uk

Michael P. W. Grocott

mike.grocott@soton.ac.uk

1 Shackleton Department of Anaesthetics, Perioperative Medicine Team, CE125, SGH, E-Level, Centre Block, University Hospital Southampton NHS Foundation Trust, Tremona Road, Southampton SO16 6YD, UK

2 Integrative Physiology and Critical Illness Group, Clinical and Experimental Sciences, Faculty of Medicine, University of Southampton, Southampton, UK

3 Respiratory and Critical Care Research Theme, Southampton NIHR Biomedical Research Centre, University Hospital Southampton NHS Foundation Trust, Anaesthesia and Critical Care, Southampton, UK

\section{Introduction}

Cardiopulmonary exercise testing (CPET) provides a non-invasive, dynamic and integrative assessment of the cardiovascular, pulmonary and musculoskeletal systems' response to physiological stress and provides an objective evaluation of cardiorespiratory fitness or functional capacity. CPET combines measurement of breath-by-breath expired gas with the simultaneous monitoring of heart rate (HR), blood pressure, oxygen saturations and electrocardiography (ECG). Over the last decade, CPET has increasingly been used in preoperative evaluation, and in the UK, a recent survey reported that approximately 30,000 tests are performed annually in surgical patients $[1 \bullet, 2 \bullet \cdot$. With an increasingly frail and comorbid surgical population who may have limited life expectancy even in the absence of their surgical disease, the risks and benefits of surgery may be difficult to evaluate. CPET as an objective measure of functional capacity has been used to predict perioperative risk [3], to contribute to shared 
decision-making and consent [2], to triage to perioperative critical care-enhanced environments $[4,5]$, to diagnose and evaluate the severity of comorbidities and increasingly to direct preoperative exercise training programmes as an element of prehabilitation $[6 \cdot, 7]$.

\section{Exercise Capacity, Ventilatory Equivalents and Surgical Outcome}

The perioperative CPET literature focuses on incremental exercise testing to the limit of tolerance (symptom limited ramp or incremental exercise test) using cycle ergometry, and three main indices of cardiorespiratory fitness and cardiorespiratory function are reported in relation to surgical outcome. These are:

1. Peak oxygen uptake ( $\mathrm{VO}_{2}$ peak), defined as the highest $\dot{V}$ $\mathrm{O}_{2}$ attained on a rapid incremental test expressed in $\mathrm{mlkg}^{-1} \mathrm{~min}^{-1}$ or $\mathrm{ml}^{-\mathrm{min}^{-1}}$ absolute.

2. Anaerobic threshold (AT), a submaximal index of exercise capacity defined as the oxygen uptake $\left(\mathrm{VO}_{2}\right)$ above which there is a metabolic transition to increased glycolysis and lactate begins to rise with an associated metabolic acidosis, expressed in $\mathrm{mlkg}^{-1} \mathrm{~min}^{-1}$ or $\mathrm{ml}^{-\mathrm{min}^{-1}}$ absolute.

3. The ventilatory equivalent for carbon dioxide $\left(\dot{\mathrm{V}}_{\mathrm{E}} / \mathrm{V} \mathrm{CO}_{2}\right)$ defined as the ratio of minute ventilation to carbon dioxide production usually reported at the AT.

Impairments in $\dot{\mathrm{VO}}_{2}$ peak $[8,9]$, AT $[10,11]$ and $\dot{\mathrm{V}}_{\mathrm{E}} / \mathrm{VCO}_{2}$ [12-14] (and thus reduced physiological reserve) are associated with an increased risk of postoperative morbidity and mortality following major noncardiac surgery $[3,15]$. $\mathrm{VO}_{2}$ peak is interpreted as the maximal exercise capacity limited by oxygen delivery to the tissues. In reality it reflects the patient's "best effort" on that day but is not necessarily a physiologically limited endpoint as it may be affected by the patient's volition. $\mathrm{VO}_{2}$ peak can only be assumed to reflect the patient's physiological limits if $\mathrm{VO}_{2}$ plateaus as the limit of tolerance is approached (defined as $\mathrm{V}_{2}$ max). Surrogate endpoints that are used in healthy subjects to determine whether the effort was maximal in the absence of a plateau in $\mathrm{VO}_{2}$ are problematic in a clinical population where drugs which affect the chronotropic response are common (e.g. beta blockade). Likewise using the generation of a significant metabolic acidosis (Respiratory exchange ratio (RER) > 1.15 at peak exercise) as an index of maximal effort may be invalid in a patient with limiting respiratory disease. Thus $\mathrm{VO}_{2}$ peak, although easy to determine, may be affected by factors other than functional capacity or fitness. Despite these limitations however, it has been consistently linked to clinical outcomes after surgery and in cardiac disease [15]. The anaerobic threshold is an index of sustainable exercise capacity, marking a metabolic transition during incremental exercise from predominantly oxidative phosphorylation to an increasing proportion of glycolysis which is ultimately unsustainable. The AT cannot be influenced by volition, but identification is more complex, and consequently inter-rater reliability is less than for $\mathrm{VO}_{2}$ peak [16]. Furthermore, AT cannot be reliably identified in approximately $5 \%$ of cases (particularly in the presence of chronic lung disease) [17]. The ventilatory equivalent for carbon dioxide $\left(\dot{\mathrm{V}}_{\mathrm{E}} / \mathrm{VCO}_{2}\right)$ is an index of gas exchange efficiency. In the perioperative literature, predominantly the $\dot{\mathrm{V}}_{\mathrm{E}} / \dot{\mathrm{V}} \mathrm{CO}_{2}$ at the AT is reported. However in the absence of a discernible AT, the minimum recorded value or the gradient of the $\dot{\mathrm{V}}_{\mathrm{E}} / \mathrm{VCO}_{2}$ slope is approximately equivalent and can be used instead [17]. Thus an index of $\dot{V}_{E} /$ $\dot{\mathrm{V} C O} \mathrm{O}_{2}$ should be obtained in all incremental exercise tests. $\dot{\mathrm{V}}_{\mathrm{E}} /$ $\dot{\mathrm{V} C O}{ }_{2}$ is a measure of gas exchange efficiency rather than exercise capacity per se and reflects both ventilationperfusion matching and physiological dead space. It is elevated and has prognostic value in heart failure (HF) and chronic obstructive pulmonary disease (COPD), pulmonary hypertension and other respiratory disease. In the perioperative setting, it has been reported as predicting postoperative complications (particularly cardiopulmonary complications) $[12,13]$ and long-term mortality [14].

CPET as a part of preoperative evaluation in noncardiothoracic surgery was first proposed in the early 1990 s by Older and colleagues [18 •. $]$ who observed an association between reduced AT and worsened postoperative outcomes following major intra-cavity surgery. Specifically an AT $<11 \mathrm{ml} \cdot \mathrm{kg}^{-1} \cdot \mathrm{min}^{-1}$ was associated with a higher incidence of postoperative mortality. Prior to this, $\dot{\mathrm{VO}}_{2}$ peak had been used in thoracic surgery to identify high-risk patients for lung resection surgery [8]. Subsequently, observational studies have supported the use of CPET for preoperative risk evaluation across a variety of surgical specialties including colorectal $[19,20]$, intra-abdominal [12, 18], vascular [13, 21], urological [22, 23], bariatric [24], thoracic [8, 9], oesophageal [25, 26] and hepatobiliary $[10,27]$ (including liver transplant surgery $[10,28])$. Table 1 summarises the major cohort studies and risk thresholds, and the reader is referred to a number of recent review articles in this area for an exhaustive list of relevant studies [2, 29•]. In the vast majority of cohorts, exercise capacity expressed as either $\mathrm{VO}_{2}$ peak or AT is associated with postoperative morbidity and mortality. Of note unlike many other risk prediction tools for noncardiac surgery which focus on cardiac risk specifically, CPET predicts all-cause morbidity including respiratory complications and sepsis which in most case series are more prevalent than cardiac complications $[11,30]$. 
Table 1 Predictive role of CPET in non-cardiothoracic surgery

\begin{tabular}{|c|c|c|c|c|c|}
\hline First author [ref] & $\mathrm{n}$ & $\begin{array}{l}\text { AT } \\
\text { risk threshold } \\
\left(\mathrm{ml}^{1} \mathrm{~kg}^{-1} \mathrm{~min}^{-1}\right)\end{array}$ & $\begin{array}{l}\mathrm{VO}_{2} \text { peak } \\
\text { risk threshold } \\
\left(\mathrm{ml}^{-} \mathrm{kg}^{-1} \mathrm{~min}^{-1}\right)\end{array}$ & $\begin{array}{l}\dot{\mathrm{V}}_{\mathrm{E}} / \dot{\mathrm{VCO}}_{2} \\
\text { risk threshold }\end{array}$ & Outcome \\
\hline \multicolumn{6}{|l|}{ Intra-abdominal surgery } \\
\hline Older [18] & 187 major intra-abdominal & $<11$ & NM & NM & Mortality: IH \\
\hline Older [5] & 548 major intra-abdominal & $<11$ & NM & $\mathrm{N}$ & Mortality: IH \\
\hline Wilson [12] & 847 intra-abdominal & $<10.9$ & NM & $>34$ & Mortality: 90 days \\
\hline Snowden [11] & 116 intra-abdominal & $<10.1$ & Excluded in model & $\mathrm{N}$ & Morbidity: POMS \\
\hline Hightower [98] & 32 intra-abdominal & $<60 \%$ pred AT & $\mathrm{N}$ & NM & Morbidity: SD \\
\hline Colson [99] & 1725 major thoraco-abdominal & $\mathrm{N}$ & $\mathrm{N}$ & $\mathrm{N}$ & Mortality: 30 -day/1-year/5-year \\
\hline James [100] & 83 intra-abdominal & $<10.6$ & $<14$ & NM & Morbidity: SD \\
\hline \multicolumn{6}{|l|}{ Colorectal surgery } \\
\hline Lai [101] & 269 colorectal surgery & $<11$ & NM & NM & $\begin{array}{l}\text { Mortality: } 2 \text { years } \\
\text { Morbidity: LOS }\end{array}$ \\
\hline West [19] & 136 colon resections & $<10.1$ & $<16.7$ & 32.9 & Morbidity: POMS, CD \\
\hline West [20] & 105 rectal resections & $<10.6$ & $<18.6$ & $\mathrm{~N}$ & Morbidity: POMS, CD \\
\hline \multicolumn{6}{|l|}{ AAA surgery } \\
\hline Nugent [102] & $30 \mathrm{AAA}$ & $\mathrm{N}$ & $\mathrm{N}$ & NM & Mortality: 1 year \\
\hline Carlisle [13] & $130 \mathrm{AAA}$ & Y, no cut-off value & Y, no cut-off value & $>42$ & Mortality: Median 35 months \\
\hline Thompson [103] & 102 AAA & $<11$ & $\mathrm{~N}$ & $\mathrm{~N}$ & $\begin{array}{l}\text { Mortality: } 30 \text { months } \\
\text { Morbidity: CD } 30 \text { days \& SD }\end{array}$ \\
\hline Hartley [104] & $415 \mathrm{AAA}$ & $<10.2$ & $<15$ & $>42$ & Mortality: 30 days/90 days \\
\hline Prentis [105] & $185 \mathrm{AAA}$ & $<10$ & $\begin{array}{l}\text { Y, no cut-off value } \\
\text { Odds ratio }\end{array}$ & $\mathrm{N}$ & Morbidity: SD, LOS \\
\hline Goodyear [106] & 188 AAA & Y, no cut-off value & NM & NM & $\begin{array}{l}\text { Mortality: } 30 \text { days } \\
\text { Morbidity: LOS }\end{array}$ \\
\hline Grant [21] & $506 \mathrm{AAA}$ & $<10.2$ & $<15$ & $>42$ & Mortality: 3 years \\
\hline Rose [107] & 124 AAA & $\mathrm{N}$ & $<13.1$ & $\geq 34$ & Mortality: 2 year \\
\hline \multicolumn{6}{|l|}{ Hepatobiliary surgery } \\
\hline Epstein [108] & 59 liver transplant & $<50 \%$ pred & $<60 \%$ pred & NM & Mortality: 100 days \\
\hline Ausania [27] & 124 whipples & $\mathrm{N}$ & NM & $\mathrm{N}$ & Morbidity: PFD, POMS \\
\hline Ausania [109] & 50 pancreatic surgery & $\mathrm{N}$ & NM & $\mathrm{N}$ & Morbidity: POMS \\
\hline Junejo [110] & 108 hepatic resection & $<9.9$ & $\mathrm{~N}$ & $>34.5$ & $\begin{array}{l}\text { Mortality: IH } \\
\text { Morbidity: POMS }\end{array}$ \\
\hline Prentis [111] & 60 liver transplant & $<9$ & $\mathrm{~N}$ & $\mathrm{~N}$ & Mortality: 90 days \\
\hline Chandrabalan [112] & 100 pancreatic surgery & $<10$ & NM & NM & Morbidity: PFD, CD, LOS \\
\hline Kaibori [113] & 61 hepatectomy & $<11.5$ & $<16.5$ & $\mathrm{~N}$ & $\begin{array}{l}\text { Mortality: } 2 \text { years } \\
\text { Morbidity: CD }\end{array}$ \\
\hline Bernal [114] & 223 liver transplant & $<9.2$ & $<13.4$ & NM & $\begin{array}{l}\text { Mortality: } 1 \text { year } \\
\text { Morbidity: LOS }\end{array}$ \\
\hline Snowden [10] & 389 major hepatobilary & $<10.1$ & $\mathrm{~N}$ & $\mathrm{~N}$ & $\begin{array}{l}\text { Mortality: IH } \\
\text { Morbidity: LOS }\end{array}$ \\
\hline Dunne [115] & 197 liver surgery & $\mathrm{N}$ & $\mathrm{N}$ & $\mathrm{N}$ & Morbidity: CD, LOS \\
\hline Junejo [116] & 64 pancreatico-duodenectomy & $\mathrm{N}$ & $\mathrm{N}$ & $>41$ & $\begin{array}{l}\text { Mortality: } 30 \text { days } \\
\text { Morbidity: SD }\end{array}$ \\
\hline Neviere [28] & 263 liver transplant & $\mathrm{N}$ & $<17.1$ & $\mathrm{~N}$ & $\begin{array}{l}\text { Primary composite endpoint including } \\
1 \text { year mortality } \\
\text { Morbidity: SD }\end{array}$ \\
\hline \multicolumn{6}{|c|}{ Upper gastrointestinal surgery } \\
\hline Nagamatsu [26] & 52 oesophagectomy & Y, no cut-off value & Y, no cut-off value & NM & Morbidity: SD \\
\hline Nagamatsu [25] & 91 oesophagectomy & & $800 \mathrm{~mL} \cdot \min ^{-1} \cdot \mathrm{m}^{-1}$ & NM & Morbidity: SD \\
\hline McCullough [24] & 109 bariatric & $<10.5$ & $<15.8$ & $\mathrm{~N}$ & $\begin{array}{l}\text { Primary composite end-point including } \\
\text { IH mortality }\end{array}$ \\
\hline Hennis [117] & 106 bariatric & $<11.1$ & $\mathrm{~N}$ & $\mathrm{~N}$ & Morbidity: POMS, LOS \\
\hline Moyes [118] & 108 upper GI & $<9.0$ & $\mathrm{~N}$ & $\mathrm{~N}$ & Morbidity: SD \\
\hline \multicolumn{6}{|l|}{ Urological surgery } \\
\hline Ulubay [119] & 37 renal and cardiac transplant & $<9.5$ & $\mathrm{~N}$ & $>53.6$ & $\begin{array}{l}\text { Mortality: IH } \\
\text { Morbidity: SD }\end{array}$ \\
\hline Ting [120] & 70 renal transplant & $<9.4$ & $<14.9$ & $\mathrm{~N}$ & Mortality: 5 years \\
\hline Prentis [22] & 82 radical cystectomy & $<12$ & $\mathrm{~N}$ & $\mathrm{~N}$ & Morbidity: CD, LOS \\
\hline Tolchard [23] & 105 radical cystectomy & $<11$ & $\mathrm{~N}$ & $>33$ & Morbidity: CD, LOS \\
\hline
\end{tabular}

$A T$ anaerobic threshold; $A A A$ abdominal aortic aneurysm; $N$ no; $N M$ not measured; $I H$ in-hospital; POMS postoperative morbidity survey; $\%$ pred $\%$ predicted; $C D$ Clavien-Dindo complication; $S D$ self-defined; $L O S$ length of stay: $P F D$ pancreatic fistula definition; $\dot{V}_{E} \dot{V} C O_{2}$ ventilatory equivalent for carbon dioxide; $\dot{V} \mathrm{O}_{2}$ peak peak oxygen consumption. Reproduced and updated from [15] with permission

More recent studies have focused on the use of $\dot{\mathrm{V}}_{\mathrm{E}} / \mathrm{VCO}_{2}$ to predict complications after lung resection surgery [31], where it may have greater predictive precision than $\mathrm{VO}_{2}$ peak and in the prediction of long-term mortality postoperatively [14]. The
CPET literature is, however, limited by the fact that the majority of reports are retrospective and single centre, although recently multicentre cohorts have been reported [32-34, 35*0]. The predictive precision of CPET varies in reported case cohorts, and it 
is notable that it tends to be greater in blinded cohorts than unblinded cohorts which may reflect confounding by indication [2]. The thresholds for identifying a high-risk group also differ in different surgical cohorts and surgical procedures which probably reflect variation in the physiological stress induced by the procedure (e.g. open oesophagectomy vs laparoscopic colorectal surgery). Overall there has been a tendency for the exercise capacity thresholds at which risk increases to decrease over time [11], (e.g. the AT reported risk thresholds falling from 11 to $9-10 \mathrm{ml} \mathrm{kg}^{-1} \mathrm{~min}^{-1}$ in some types of surgery) possibly because of evolution in surgical techniques (e.g. laparoscopic surgery) and improvements in perioperative care. There is a need for ongoing multicentre, prospective cohort data to define contemporaneous risk thresholds. Of note, the recent large prospective and blinded Measurement of Exercise Tolerance before Surgery (METS) study compared the prognostic accuracy of a variety of methods of assessing preoperative functional capacity (including subjective clinical assessment). CPET was found to be the only test predictive of in-hospital moderate or severe complications [35]. The Duke Activity Status Index (DASI) questionnaire (a physical activity questionnaire designed for cardiac patients) and beta natriuretic protein (BNP) were better at predicting myocardial infarction (MI) and myocardial injury and mortality at 1 year. This cohort study aimed to evaluate a high-risk surgical population but the overall mortality was only $0.4 \%$ (a low risk population). This may reflect a "healthy bias" effect which is common in exercise studies generally, whereby the study participants are fitter than the population mean. The average $\dot{\mathrm{VO}}_{2}$ peak at $19.2 \mathrm{ml} \mathrm{kg}^{-1} \mathrm{~min}^{-1}$ in the study is higher than in unselected retrospective cohort studies. The design of future studies should take this effect into account when predicting event rates to ensure the study is adequately powered [36]. Of note new arrhythmias or myocardial ischaemia were detected in 27 cases during CPET in the METS study leading to unblinding of clinicians and a significant change in management for the patients. These changes included delaying the surgical procedure for investigation such as angiography, referring to other medical specialists for optimisation and changing the previously planned surgical procedure. This illustrates CPET's potential role in the detection and optimisation of both known and previously undiagnosed comorbidity even in a low risk population.

\section{Novel and Emerging CPET Variables for Preoperative Evaluation}

\section{Oxygen Pulse}

There is physiological rationale and emerging evidence to support the utility of several other CPET variables in perioperative risk prediction. The oxygen pulse provides an indirect assessment of dynamic stroke volume and oxygen extraction under stress. Oxygen pulse is defined as the ratio of oxygen consumption to $\mathrm{HR}\left(\mathrm{VO}_{2} / \mathrm{HR}\right)$ and is the volume of oxygen ejected with each cardiac contraction. As can be derived from the Fick equation, $\left[\left(\mathrm{V}_{2}=\mathrm{Q}\right.\right.$ $\left.(\mathrm{SV} \times \mathrm{HR}) \times\left(\mathrm{Ca}_{\mathrm{O} 2}-\mathrm{Cv}_{\mathrm{O} 2}\right)\right]$, where $\mathrm{Q}$ is cardiac output, $\mathrm{SV}$ is stroke volume and $\mathrm{Ca}_{2}-\mathrm{CvO}_{2}$ is the difference between arterial and venous oxygen content $\left(\mathrm{O}_{2}\right.$ extraction), it equates to the product of stroke volume and the arterial oxygen extraction. However, a note of caution should be raised. Despite the $\mathrm{VO}_{2} / \mathrm{HR}$ being widely reported and interpreted clinically as a surrogate marker of exercise SV, whether this relationship holds true during incremental ramp exercise remains to be fully elucidated and thus $\mathrm{VO}_{2} / \mathrm{HR}$ should not be interpreted as a definitive indicator of cardiac disease in isolation. The profile of the oxygen pulse is abnormal (flattened) in the presence of exercise induced ischaemia [37], significant aortic stenosis or a dynamic impairment in ventricular function [38]. The peak oxygen pulse is reduced in cardiac failure but also impacted by other factors independently of changes in SV such as general deconditioning/training status, medications (e.g. beta blockers), pulmonary arterial hypertension, anaemia and in lung disease (particularly in cases where exercise induced desaturation occurs). Recent work found an association between a reduced oxygen pulse $(<90 \%$ of populationpredicted normal values) and lower preoperative arterial pulse pressure $(\leq 53 \mathrm{mmHg})$, the latter being associated with excess morbidity in a cohort of high-risk surgical patients [39]. The prognostic implication of peak oxygen pulse requires further evaluation in multifactorial models along with other possible indicators of increased cardiac risk such as increased preoperative BNP.

\section{Oxygen Uptake Efficiency Slope}

The oxygen uptake efficiency slope (OUES) was first proposed as a potentially useful measure of cardiorespiratory reserve by Baba and colleagues [40•]. OUES is derived from the relationship between $\dot{\mathrm{VO}}_{2}\left(\mathrm{ml} \cdot \mathrm{min}^{-1}\right)$ and logarithmically transformed minute ventilation $\left(\mathrm{VE}, \mathrm{L} \cdot \mathrm{min}^{-1}\right)$ during incremental exercise and represents the effectiveness of $\mathrm{VO}_{2}$ that is related to both metabolic acidosis and pulmonary dead space. In common with the measurement of AT, one benefit of the OUES is that it can be obtained from a submaximal test, and so it is not as dependent on patient volition as a $\mathrm{VO}_{2}$ measurement. It may also be useful in patients who are unable to perform a maximal exercise test as may be the case in morbid obesity [41] and those with poor mobility or joint problems. It is therefore possible to obtain useful data for the vast majority of patients. OUES shows excellent test retest reliability $[42,43]$ and 
is positively correlated with $\mathrm{VO}_{2}$ peak [44-46] and AT ( $r=0.80, p<0.001$ ) [45]. In addition, OUES is a sensitive and specific predictor of clinically utilised AT risk thresholds $\left(\leq 11 \mathrm{ml} \mathrm{kg}^{-1} \cdot \mathrm{min}^{-1}\right)$, with an area under the curve $(95 \% \mathrm{CI})$ of $0.876(0.780-0.972, p<0.001)$ [46]. This suggests that OUES may provide a valid measure of preoperative cardiorespiratory fitness and assist in discriminating those at higher risk of postoperative morbidity, particularly where an AT cannot be determined. In the preoperative setting, the OUES has been quantified in patients with lung cancer undergoing CPET prior to lung resection [45, 47], in elderly patients scheduled for major colorectal surgery [46] and in candidates for major intracavity surgery from mixed surgical specialties [48].

In 49 lung resection candidates, OUES was lower in those experiencing postoperative cardiopulmonary complications and showed a good ability to discriminate between those with and without postoperative complications [area under the receiver operating characteristic (AUROC) curve: 0.81] [47]. Furthermore, the OUES was associated with postoperative survival in 125 patients scheduled to undergo lung surgery $(r=0.69, p<0.01)$ and correlated with $\mathrm{VO}_{2}$ peak $(r=0.69$, $p<0.01$ ) [45]. No sensitivity or specificity analysis or KaplanMeier survival estimates were reported in this study, however, which limits interpretation of the predictive precision of the OUES. Furthermore, not all studies have reported an association between OUES and outcomes, and in another cohort of 1725 patients undergoing major intra-cavity surgery, CPETderived OUES was not predictive of 30-day, 1-year or 5-year mortality. Interestingly exercise capacity variables were also not predictive of mortality in this cohort [48]. Although encouraging, the data supporting the prognostic value of OUES is limited to date due to a lack of appropriately powered prospective studies and warrants further investigation. The OUES displays prognostic value in patients with HF [49-51] and coronary artery disease (CAD) $[52,53]$ and has been shown to be responsive to physical training in patients with $\mathrm{CAD}[54$, $55]$.

\section{Haemodynamic Responses Measured during CPET}

Haemodynamic indices such as resting HR, chronotropic response during incremental exercise and HR recovery are simple and routine measures recorded during CPET that may provide a useful indicator of autonomic nervous system activity. Both an impaired HR response to exercise (chronotropic incompetence, (CI)) [56-58] and attenuated recovery of HR post exercise (labelled HR recovery (HRR)) [59-61] are associated with cardiac and all- cause mortality. In addition, an elevated resting HR has been shown to be associated with an increased risk of multiple cardiovascular outcomes including CAD, sudden cardiac death, HF, atrial fibrillation, stroke, cardiovascular disease, as well as total cancer and all-cause mortality in a dose-response manner (apart from atrial fibrillation which showed a J-shaped relationship) [62].

These haemodynamic indices have also been investigated in the perioperative setting. In 15,000 patients undergoing noncardiac surgery, raised preoperative HR $>96$ beats $\min ^{-1}$ was associated with postoperative myocardial injury after noncardiac surgery (MINS), MI and mortality within 30 days of surgery [63]. An elevated resting HR ( $>87$ beats $\mathrm{min}^{-1}$ ) was also independently associated with impaired CPET-derived $\mathrm{VO}_{2}$ peak $\left(\leq 14 \mathrm{ml}^{1} \mathrm{~kg}^{-1} \cdot \mathrm{min}^{-1}\right)$ and a delayed HRR $(\leq 6$ beats $\left.\mathrm{min}^{-1}\right)$. In addition, a CPET-derived exaggerated HR (EHRR) increase (underpinned by raised sympathetic autonomic activity) during unloaded cycling (defined as $\geq 12$ beats $\mathrm{min}^{-1}$ ) was associated with an increased risk of exercise ischaemia on ECG (defined as $>1 \mathrm{~mm}$ ST depression in lead II) and inferior cardiorespiratory fitness (AT 10.6 versus $11.1 \mathrm{ml}^{1} \mathrm{~kg}^{-1} \mathrm{~min}^{-1}$, $p=0.008 ; \mathrm{VO}_{2}$ peak $74 \%$ versus $78 \%$ of predicted, $p=0.05$ ) and reduced cardiac performance (quantified by the oxygen pulse, being a surrogate marker of left ventricular stroke volume) $85 \%$ versus $95 \%$ predicted, $p=0.0001$. This study also demonstrated a prolonged hospital stay in patients exhibiting an EHRR [64].

Impaired HRR after exercise is common with $40 \%$ occurrence being reported in the METS study [65]. Cardiac vagal dysfunction defined as a delayed HRR (where impaired HRR is defined as $\leq 12$ beats $\min ^{-1}$ measured 1-min post cessation of preoperative CPET) is also associated with an increased risk of perioperative cardiac injury (defined by serum troponin concentration within $72 \mathrm{~h}$ of undergoing noncardiac surgery) [66]. In addition, cardiorespiratory fitness is reduced in patients exhibiting an impaired HRR $\left(\mathrm{VO}_{2}\right.$ peak standard deviation [SD] 17.1 (5.6) versus $20.8(6.5) \mathrm{ml}^{-\mathrm{kg}^{-1}} \cdot \mathrm{min}^{-1}$; AT 11.6 (3.4) versus $13.4(4.4) \mathrm{ml} \mathrm{kg}^{-1} \cdot \mathrm{min}^{-1}$ ). Taken together these findings highlight that both resting and recovery haemodynamic responses that can be routinely obtained during CPET, but are rarely utilised clinically, can be used to identify a group of patients with impaired cardiopulmonary performance consistent with markers of subclinical cardiac failure prior to surgery and at increased risk of deleterious perioperative cardiac outcomes. This may allow more tailored perioperative management strategies to alleviate these risks as well as better inform the preoperative evaluation process in higher risk surgical candidates. 
A recent planned secondary analysis of two prospective, multicentre, blinded observational studies (the METS and POM-HR study) also found that all-cause morbidity (defined using the Postoperative Morbidity Survey and Clavien-Dindo grading of postoperative complications) within 5 days of noncardiac surgery was more common in patients with impaired cardiac vagal function (HRR $\leq 12$ beats $\min ^{-1}$ after preoperative CPET) than those with a normal HRR (OR: $1.29,95 \% \mathrm{CI}$ 1.06-1.58; $p=0.001$ ) [67•]. Importantly, an impaired HRR was associated with specific domains of in-hospital morbidity including more frequent episodes of cardiovascular (OR: 1.39, 95\% CI 1.15-1.69; $p<0.001$ ), pulmonary (OR: $1.31,95 \%$ CI $1.05-1.62 ; p=0.02$ ), infection (OR: $1.38,95 \%$ CI 1.10-2.70; $p=0.006$ ), renal (OR: $1.91,95 \%$ CI 1.30-2.79; $p=0.02$ ), neurological (OR: $1.73,95 \%$ CI 1.11-2.70; $p=0.02$ ) and pain morbidities (OR: 1.38, 95\% CI 1.14-1.68; $p=0.001$ ). This has important implications for patients in the immediate postoperative period but may also have longer survival consequences, given the previously reported observation that postoperative morbidity of any aetiology increases risk of death for up to 3 years after surgical intervention [68]. This data may therefore have utility in better informing collaborative/shared decision-making around the short-term and longer-term risks of surgery and thereby aid the preoperative evaluation and decision-making processes.

The chronotropic response to exercise can be defined as the ability to increase HR appropriately to match cardiac output to metabolic demands [69]. When the ability to augment HR is impaired, this is termed chronotropic incompetence (CI) [70]. CI during exercise is a predictor of major adverse cardiovascular events in patients with cardiovascular diseases [71-73] but may also be a phenotype that is associated with cardiovascular risk and impaired gas exchange (ن $\mathrm{O}_{2}$ peak) in the general population [74]. Variation in cut-off values and methods used to define CI underpin the disparity in reported prevalence rates, but figures of between $25 \%$ and $75 \%$ have been reported in HF [75-77], patients with known or suspected CAD [78] and prior to high-risk noncardiac surgery [65]. Although related to preoperative biomarker indicators of subclinical HF (N-terminal pro-B-type natriuretic peptide [NT pro-BNP] $>300 \mathrm{pg} \mathrm{ml}^{-1}$ ) and more common in patients with impaired CPET-derived cardiorespiratory fitness $\left(\dot{\mathrm{VO}}_{2}\right.$ peak $\left.\leq 14 \mathrm{ml} \cdot \mathrm{kg}^{-1} \mathrm{~min}^{-1}\right)$ and gas exchange inefficiency $\left(\dot{\mathrm{V}}_{\mathrm{E}} / \dot{\mathrm{VCO}}_{2}\right.$ slope $\left.\geq 34\right)$, preoperative chronotropic incompetence (defined as chronotropic index $(\mathrm{CI})<0.6$, a surrogate marker of sympathetic dysfunction) was not associated with postoperative myocardial injury on day 3 or 1year mortality. Whether this is the case for other markers of postoperative morbidity remains to be elucidated. The authors suggest that these findings add support to the notion that cardiac vagal dysfunction is the most important autonomic determinant of myocardial injury and perioperative outcomes $[79,80]$. Such impairments can be quantified preoperatively through the use of CPET.

\section{Alternative Testing Protocols: High Intensity Constant Work Rate Tests and Metabolic Efficiency}

The traditional CPET protocol is the incremental-ramp exercise test whereby work rate is increased linearly, or quasi-linearly, until the patient reaches their limit of tolerance, ideally performing 8-12 min of ramped exercise [81]. Constant work rate tests may also have applications in the perioperative setting.

\section{High Intensity Constant Work Rate Tests to Evaluate Exercise Interventions}

Exercise programmes either as stand-alone interventions or as part of multimodal prehabilitation are increasingly used in the preoperative period. A test that is sensitive to changes in fitness is required to evaluate the efficacy of such interventions. A high intensity constant work rate test at $75 \%-80 \%$ of the maximal work rate achieved on an incremental exercise test is more sensitive to changes in fitness than $\mathrm{VO}_{2}$ peak and AT or the 6-min walk test [82]. The tolerance time or endurance time (tLIM) is the duration from the imposition of the work rate to the point of task failure expressed in seconds or minutes. The clinically meaningful difference for a prehabilitation exercise intervention is unknown, although it is of note that in the one prospective randomised controlled trial of prehabilitation to demonstrate a $50 \%$ reduction in postoperative complications, there was a $135 \%$ increase in the tLIM in the intervention group [6]. Interestingly, despite the $135 \%$ increase in tLIM, the 6-min walk test distance did not change, suggesting that it is not sensitive to clinically meaningful changes in fitness in this context.

\section{Low Intensity Constant Work Rate Tests to Evaluate Metabolic Efficiency}

CPET measures the ability of the integrated respiratorycirculatory-metabolic unit to meet the increasing $\mathrm{O}_{2}$ demands of exercise. Surgery, like exercise, places significant metabolic stress on the body and requires effective $\mathrm{O}_{2}$ delivery to the tissues and efficient $\mathrm{O}_{2}$ utilisation to aid recovery in the proinflammatory and hypermetabolic postoperative period [83]. Metabolic efficiency reflects the ratio of work generated to the total metabolic energy cost [84] and provides an index of how effectively an individual can convert chemical energy into mechanical power. The oxygen cost of any given work is reduced in an individual with enhanced metabolic efficiency. This may potentially translate into a greater physiological reserve for sustainable aerobic oxidative phosphorylation before 
supplemental anaerobic energy pathways are required to contribute to overall energy production.

The most commonly used measure of metabolic efficiency is gross efficiency, the product of (work accomplished/energy expended) $\times 100$. Energy expenditure can be calculated from the steady-state $\mathrm{VO}_{2}$ and the respiratory exchange ratio (RER) measured during a sub-anaerobic threshold constant work rate test [83] and from this metabolic efficiency can be determined. Pedalling cadence must be standardised as it influences efficiency, and a test duration of at least $6 \mathrm{~min}$ is required to ensure that steady-state $\dot{\mathrm{VO}}_{2}$ and $\dot{\mathrm{VCO}}_{2}$ are achieved. Skeletal muscle efficiency reflects mitochondrial function and efficiency $[85,86]$. Mitochondrial dysfunction and mitochondrial coupling inefficiency have been directly implicated in the reduced exercise efficiency observed with age [87, 88], greater fatigability in older subjects [89], sarcopenia and cancer cachexia, type 2 diabetes [85], impairments in aerobic capacity [90],all conditions commonly observed in a surgical population. Skeletal muscle efficiency has not been reported in surgical patients to date; however, it provides a potential opportunity for targeted intervention to improve exercise performance given that it is at least in part determined by mitochondrial function. Exercise training induces changes in mitochondrial volume, density and enzyme activity [91, 92,93, 94], and there is a suggestion that mitochondrial coupling efficiency may be improved with dietary nitrate supplementation although this is controversial [95-97].

\section{Conclusion}

In summary, CPET informs the preoperative evaluation process by providing individualised risk profiles; guiding shared decision-making, comorbidity optimisation and preoperative exercise training; and informing perioperative patient management. $\dot{\mathrm{VO}}_{2}$ peak, AT and $\dot{\mathrm{V}}_{\mathrm{E}} / \mathrm{VCO}_{2}$ at $\mathrm{AT}$ have been the CPET variables routinely used for risk prediction, and the literature supports an association between exercise capacity and surgical outcome. Future risk prediction studies should prospectively evaluate CPET variables in combination with other known predictors of outcome such as BNP, renal function and albumin in prospective cohorts. CPET can both quantify exercise capacity and identify the cause of exercise intolerance, which provides an opportunity for targeted optimisation of known and newly identified comorbidities in the preoperative period (e.g. rate control in atrial fibrillation). Although CPET provides a wealth of physiological data, to date much of this is underutilised clinically. For example, impaired chronotropic responses during and after CPET are simple to measure and in recent studies are predictive of both cardiac and noncardiac morbidity following surgery but are rarely reported. Exercise interventions are increasingly being used preoperatively, and
tLIM derived from a high intensity constant work rate test should be considered as the most sensitive method of evaluating the response to training. Further research is required to identify the clinically meaningful difference in tLIM. Measuring efficiency may have utility, but this requires exploration in prospective studies.

\section{Compliance with Ethical Standards}

Conflict of Interest The authors declare that they have no conflict of interest.

Human and Animal Rights and Informed Consent James Otto performed routine CPET as part of a patient's standard clinical care whose data was included in the POM-HR study. James Otto also performed CPET on patients at University College London Hospital who were enrolled into the METS study.

Open Access This article is licensed under a Creative Commons Attribution 4.0 International License, which permits use, sharing, adaptation, distribution and reproduction in any medium or format, as long as you give appropriate credit to the original author(s) and the source, provide a link to the Creative Commons licence, and indicate if changes were made. The images or other third party material in this article are included in the article's Creative Commons licence, unless indicated otherwise in a credit line to the material. If material is not included in the article's Creative Commons licence and your intended use is not permitted by statutory regulation or exceeds the permitted use, you will need to obtain permission directly from the copyright holder. To view a copy of this licence, visit http://creativecommons.org/licenses/by/4.0/.

\section{References}

Papers of particular interest, published recently, have been highlighted as:

- Of importance

•. Of major importance

1. Reeves T, Bates S, Sharp T, Richardson K, Bali S, Plumb J, et al. Cardiopulmonary exercise testing (CPET) in the United Kingdom-a national survey of the structure, conduct, interpretation and funding. Perioper Med (Lond). 2018;7:2. https://doi.org/10.1186/s13741-0170082-3 Updated survey highlighting the continued expansion of perioperative CPET services in the United Kingdom.

2.• Older PO, Levett DZH. Cardiopulmonary exercise testing and surgery. Ann Am Thorac Soc. 2017;14(Supplement 1):S74-83. https://doi.org/10.1513/AnnalsATS.201610-780FR This comprehensive review article provides the reader with evidence supporting the predictive role of CPET in surgical outcomes and for pre-operative evaluation.

3. Moran J, Wilson F, Guinan E, McCormick P, Hussey J, Moriarty J. Role of cardiopulmonary exercise testing as a risk-assessment method in patients undergoing intra-abdominal surgery: a systematic review. Br J Anaesth. 2016;116(2):177-91. https://doi.org/10. 1093/bja/aev454.

4. Swart M, Carlisle JB, Goddard J. Using predicted 30 day mortality to plan postoperative colorectal surgery care: a cohort study. Br J Anaesth. 2017;118(1):100-4. https://doi.org/10.1093/bja/aew402. 
5. Older P, Hall A, Hader R. Cardiopulmonary exercise testing as a screening test for perioperative management of major surgery in the elderly. Chest. 1999;116(2):355-62.

6. Barberan-Garcia A, Ubre M, Roca J, Lacy AM, Burgos F, Risco R, et al. Personalised Prehabilitation in High-risk Patients Undergoing Elective Major Abdominal Surgery: A Randomized Blinded Controlled Trial. Ann Surg. 2018;267(1):50-6. https:// doi.org/10.1097/SLA.0000000000002293 Study highlighting that endurance time derived from a high intensity constant work rate test should be considered the most sensitive method of evaluating the response to training. This has important implications as part of prehabilitation in advance of surgery.

7. West MA, Loughney L, Lythgoe D, Barben CP, Sripadam R, Kemp GJ, et al. Effect of prehabilitation on objectively measured physical fitness after neoadjuvant treatment in preoperative rectal cancer patients: a blinded interventional pilot study. Br J Anaesth. 2015;114(2):244-51. https://doi.org/10.1093/bja/aeu318.

8. Brunelli A, Belardinelli R, Refai M, Salati M, Socci L, Pompili C, et al. Peak oxygen consumption during cardiopulmonary exercise test improves risk stratification in candidates to major lung resection. Chest. 2009;135(5):1260-7. https://doi.org/10.1378/chest.08-2059.

9. Bayram AS, Candan T, Gebitekin C. Preoperative maximal exercise oxygen consumption test predicts postoperative pulmonary morbidity following major lung resection. Respirology. 2007;12(4):505-10. https://doi.org/10.1111/j.1440-1843.2007.01097.x.

10. Snowden CP, Prentis J, Jacques B, Anderson H, Manas D, Jones $\mathrm{D}$, et al. Cardiorespiratory fitness predicts mortality and hospital length of stay after major elective surgery in older people. Ann Surg. 2013;257(6):999-1004. https://doi.org/10.1097/SLA. 0b013e31828dbac2.

11. Snowden CP, Prentis JM, Anderson HL, Roberts DR, Randles D, Renton M, et al. Submaximal cardiopulmonary exercise testing predicts complications and hospital length of stay in patients undergoing major elective surgery. Ann Surg. 2010;251(3):535-41. https://doi.org/10.1097/SLA.0b013e3181cf811d.

12. Wilson RJ, Davies S, Yates D, Redman J, Stone M. Impaired functional capacity is associated with all-cause mortality after major elective intra-abdominal surgery. Br J Anaesth. 2010;105(3): 297-303. https://doi.org/10.1093/bja/aeq128.

13. Carlisle J, Swart M. Mid-term survival after abdominal aortic aneurysm surgery predicted by cardiopulmonary exercise testing. Br J Surg. 2007;94(8):966-9. https://doi.org/10.1002/bjs.5734.

14. Wilson RJT, Yates DRA, Walkington JP, Davies SJ. Ventilatory inefficiency adversely affects outcomes and longer-term survival after planned colorectal cancer surgery. Br J Anaesth. 2019;123(2):238-45. https://doi.org/10.1016/j.bja.2019.01.032.

15. Harvie D, Levett DZH. Exercise testing for pre-operative evaluation. In: Palange P, Laveneziana P, Neder JA, editors. Clinical exercise testing (ERS monograph). Sheffield: European Respiratory Society; 2018. p. 251-79.

16. Abbott TEF, Gooneratne M, McNeill J, Lee A, Levett DZH, Grocott MPW, et al. Inter-observer reliability of preoperative cardiopulmonary exercise test interpretation: a cross-sectional study. Br J Anaesth. 2018;120(3):475-83. https://doi.org/10.1016/j.bja.2017.11.071.

17. Levett DZH, Jack S, Swart M, Carlisle J, Wilson J, Snowden C, et al. Perioperative cardiopulmonary exercise testing (CPET): consensus clinical guidelines on indications, organization, conduct, and physiological interpretation. Br J Anaesth. 2018;120(3):484 500. https://doi.org/10.1016/j.bja.2017.10.020.

18.• Older P, Smith R, Courtney P, Hone R. Preoperative evaluation of cardiac failure and ischemia in elderly patients by cardiopulmonary exercise testing. Chest. 1993;104(3):701-4 Seminal paper reporting an association between pre-operative fitness and post-operative mortality that has strongly influenced preoperative risk evaluation.
19. West MA, Lythgoe D, Barben CP, Noble L, Kemp GJ, Jack S, et al. Cardiopulmonary exercise variables are associated with postoperative morbidity after major colonic surgery: a prospective blinded observational study. Br J Anaesth. 2014;112(4):665-71. https://doi.org/10.1093/bja/aet408.

20. West MA, Parry MG, Lythgoe D, Barben CP, Kemp GJ, Grocott MP, et al. Cardiopulmonary exercise testing for the prediction of morbidity risk after rectal cancer surgery. Br J Surg. 2014;101(9): 1166-72. https://doi.org/10.1002/bjs.9551.

21. Grant SW, Hickey GL, Wisely NA, Carlson ED, Hartley RA, Pichel AC, et al. Cardiopulmonary exercise testing and survival after elective abdominal aortic aneurysm repair. $\mathrm{Br} \mathrm{J}$ Anaesth. 2015;114(3):430-6. https://doi.org/10.1093/bja/aeu383.

22. Prentis JM, Trenell MI, Vasdev N, French R, Dines G, Thorpe A, et al. Impaired cardiopulmonary reserve in an elderly population is related to postoperative morbidity and length of hospital stay after radical cystectomy. BJU Int. 2013;112(2):E13-9. https://doi.org/ 10.1111/bju.12219.

23. Tolchard S, Angell J, Pyke M, Lewis S, Dodds N, Darweish A, et al. Cardiopulmonary reserve as determined by cardiopulmonary exercise testing correlates with length of stay and predicts complications after radical cystectomy. BJU Int. 2015;115(4):554-61. https://doi.org/10.1111/bju.12895.

24. McCullough PA, Gallagher MJ, Dejong AT, Sandberg KR, Trivax $\mathrm{JE}$, Alexander D, et al. Cardiorespiratory fitness and short-term complications after bariatric surgery. Chest. 2006;130(2):517-25. https://doi.org/10.1378/chest.130.2.517.

25. Nagamatsu Y, Yamana H, Fujita H, Hiraki H, Matsuo T, Mitsuoka $\mathrm{M}$, et al. The simultaneous evaluation of preoperative cardiopulmonary functions of esophageal cancer patients in the analysis of expired gas with exercise testing. [Zasshi] [Journal] Nihon Kyobu Geka Gakkai. 1994;42(11):2037-40.

26. Nagamatsu Y, Shima I, Yamana H, Fujita H, Shirouzu K, Ishitake T. Preoperative evaluation of cardiopulmonary reserve with the use of expired gas analysis during exercise testing in patients with squamous cell carcinoma of the thoracic esophagus. J Thorac Cardiovasc Surg. 2001;121(6):1064-8. https://doi.org/10.1067/mtc.2001.113596.

27. Ausania F, Snowden CP, Prentis JM, Holmes LR, Jaques BC, White SA, et al. Effects of low cardiopulmonary reserve on pancreatic leak following pancreaticoduodenectomy. Br J Surg. 2012;99(9):1290-4. https://doi.org/10.1002/bjs.8859.

28. Neviere R, Edme JL, Montaigne D, Boleslawski E, Pruvot FR, Dharancy S. Prognostic implications of preoperative aerobic capacity and exercise oscillatory ventilation after liver transplantation. Am J Transplant. 2014;14(1):88-95. https://doi.org/10.1111/ajt.12502.

29. Harvie D, Levett DHZ. Exercise testing for pre-operative evaluation. In: Palange P, Laveneziana P, Neder JA, editors. Clinical exercise testing [ERS monograph]. Sheffield: European Respiratory Society; 2018. p. 251-79. Review article on the rationale for CPET in pre-operative evaluation and evidence supporting its role in predicting surgical outcomes.

30. Fleisher LA, Linde-Zwirble WT. Incidence, outcome, and attributable resource use associated with pulmonary and cardiac complications after major small and large bowel procedures. Perioper Med (Lond). 2014;3:7. https://doi.org/10.1186/2047-0525-3-7.

31. Brunelli A, Belardinelli R, Pompili C, Xiume F, Refai M, Salati $\mathrm{M}$, et al. Minute ventilation-to-carbon dioxide output (VE/VCO2) slope is the strongest predictor of respiratory complications and death after pulmonary resection. Ann Thorac Surg. 2012;93(6): 1802-6. https://doi.org/10.1016/j.athoracsur.2012.03.022.

32. Wijeysundera DN, Pearse RM, Shulman MA, Abbott TE, Torres E, Croal BL, et al. Measurement of exercise tolerance before surgery (METS) study: a protocol for an international multicentre prospective cohort study of cardiopulmonary exercise testing prior to major non-cardiac surgery. BMJ Open. 2016;6(3):e010359. https://doi.org/10.1136/bmjopen-2015-010359. 
33. West MA, Asher R, Browning M, Minto G, Swart M, Richardson $\mathrm{K}$, et al. Validation of preoperative cardiopulmonary exercise testing-derived variables to predict in-hospital morbidity after major colorectal surgery. Br J Surg. 2016;103(6):744-52. https://doi. org/10.1002/bjs.10112.

34. Carlisle JB, Danjoux G, Kerr K, Snowden C, Swart M. Validation of long-term survival prediction for scheduled abdominal aortic aneurysm repair with an independent calculator using only preoperative variables. Anaesthesia. 2015;70(6):654-65. https://doi. org/10.1111/anae.13061.

35.• Wijeysundera DN, Pearse RM, Shulman MA, TEF A, Torres E, Ambosta A, et al. Assessment of functional capacity before major non-cardiac surgery: an international, prospective cohort study. Lancet. 2018;391(10140):2631-40. https://doi.org/10.1016/S01406736(18)31131-0 This large prospective and blinded study compared the prognostic accuracy of a variety of methods of assessing preoperative functional capacity (including subjective clinical assessment) and found CPET to be the only test predictive of in-hospital moderate or severe complications.

36. de Souto BP, Ferrandez AM, Saliba-Serre B. Are older adults who volunteer to participate in an exercise study fitter and healthier than nonvolunteers? The participation bias of the study population. J Phys Act Health. 2013;10(3):359-67.

37. Belardinelli R, Lacalaprice F, Carle F, Minnucci A, Cianci G, Perna G, et al. Exercise-induced myocardial ischaemia detected by cardiopulmonary exercise testing. Eur Heart J. 2003;24(14): 1304-13. https://doi.org/10.1016/s0195-668x(03)00210-0.

38. Wasserman K, Hansen JE, Sue DY, Stringer WW, Whipp BJ. Principles of exercise testing and interpretation including pathophysiology and clinical applications. Philadelphia: Lippincott Williams \& Wilkins; 2005.

39. Ackland GL, Abbott TEF, Pearse RM, Karmali SN, Whittle J, Minto G, et al. Arterial pulse pressure and postoperative morbidity in high-risk surgical patients. Br J Anaesth. 2018;120(1):94-100. https://doi.org/10.1016/j.bja.2017.11.009.

40. Baba R, Nagashima M, Goto M, Nagano Y, Yokota M, Tauchi N, et al. Oxygen uptake efficiency slope: a new index of cardiorespiratory functional reserve derived from the relation between oxygen uptake and minute ventilation during incremental exercise. J Am Coll Cardiol. 1996;28(6):1567-72 First study investigating the usefulness of the oxygen uptake efficiency slope as an objective sub-maximal measure of cardiorespiratory fitness.

41. Onofre T, Oliver N, Carlos R, Felismino A, Corte RC, Silva E, et al. Oxygen uptake efficiency slope as a useful measure of cardiorespiratory fitness in morbidly obese women. PLoS One. 2017;12(4):e0172894. https://doi.org/10.1371/journal.pone. 0172894.

42. Phypers BJ, Robiony-Rogers D, Pickering RM, Garden AL. Testretest reliability of the oxygen uptake efficiency slope in surgical patients. Anaesthesia. 2011;66(8):659-66. https://doi.org/10. 1111/j.1365-2044.2011.06714.x.

43. Van Laethem C, De Sutter J, Peersman W, Calders P. Intratest reliability and test-retest reproducibility of the oxygen uptake efficiency slope in healthy participants. Eur J Cardiovasc Prev Rehabil. 2009;16(4):493-8. https://doi.org/10.1097/HJR. 0b013e32832c88a8.

44. Hollenberg M, Tager IB. Oxygen uptake efficiency slope: an index of exercise performance and cardiopulmonary reserve requiring only submaximal exercise. J Am Coll Cardiol. 2000;36(1): 194-201. https://doi.org/10.1016/s0735-1097(00)00691-4.

45. Yakal S, Sofyali S, Ozkan B, Yildiz S, Toker A, Kasikcioglu E. Oxygen uptake efficiency slope and prediction of post-operative morbidity and mortality in patients with lung Cancer. Lung. 2018;196(2):255-62. https://doi.org/10.1007/s00408-018-0085-y.

46. Bongers BC, Berkel AE, Klaase JM, van Meeteren NL. An evaluation of the validity of the pre-operative oxygen uptake efficiency slope as an indicator of cardiorespiratory fitness in elderly patients scheduled for major colorectal surgery. Anaesthesia. 2017;72(10): 1206-16. https://doi.org/10.1111/anae.14003.

47. Kasikcioglu E, Toker A, Tanju S, Arzuman P, Kayserilioglu A, Dilege $\mathrm{S}$, et al. Oxygen uptake kinetics during cardiopulmonary exercise testing and postoperative complications in patients with lung cancer. Lung Cancer. 2009;66(1):85-8. https://doi.org/10. 1016/j.lungcan.2008.12.024.

48. Colson M, Baglin J, Bolsin S, Grocott MP. Cardiopulmonary exercise testing predicts $5 \mathrm{yr}$ survival after major surgery. Br J Anaesth. 2012;109(5):735-41. https://doi.org/10.1093/bja/aes263.

49. Davies LC, Wensel R, Georgiadou P, Cicoira M, Coats AJ, Piepoli $\mathrm{MF}$, et al. Enhanced prognostic value from cardiopulmonary exercise testing in chronic heart failure by non-linear analysis: oxygen uptake efficiency slope. Eur Heart J. 2006;27(6):684-90. https://doi.org/10.1093/eurheartj/ehi672.

50. Myers J, Arena R, Dewey F, Bensimhon D, Abella J, Hsu L, et al. A cardiopulmonary exercise testing score for predicting outcomes in patients with heart failure. Am Heart J. 2008;156(6):1177-83. https://doi.org/10.1016/j.ahj.2008.07.010.

51. Toste A, Soares R, Feliciano J, Andreozzi V, Silva S, Abreu A, et al. Prognostic value of a new cardiopulmonary exercise testing parameter in chronic heart failure: oxygen uptake efficiency at peak exercise - comparison with oxygen uptake efficiency slope. Rev Port Cardiol. 2011;30(10):781-7. https://doi.org/10.1016/ S0870-2551(11)70026-9.

52. Coeckelberghs E, Buys R, Goetschalckx K, Cornelissen VA, Vanhees L. Prognostic value of the oxygen uptake efficiency slope and other exercise variables in patients with coronary artery disease. Eur J Prev Cardiol. 2016;23(3):237-44. https://doi.org/10. 1177/2047487315569410.

53. Buys R, Coeckelberghs E, Cornelissen VA, Goetschalckx K, Vanhees L. Prognostic value of the post-training oxygen uptake efficiency slope in patients with coronary artery disease. Eur J Prev Cardiol. 2016;23(13):1363-71. https://doi.org/10.1177/ 2047487316643446.

54. Defoor J, Schepers D, Reybrouck T, Fagard R, Vanhees L. Oxygen uptake efficiency slope in coronary artery disease: clinical use and response to training. Int J Sports Med. 2006;27(9):730-7. https://doi.org/10.1055/s-2005-872910.

55. Prado DM, Rocco EA, Silva AG, Rocco DF, Pacheco MT, Silva $\mathrm{PF}$, et al. Effects of continuous vs interval exercise training on oxygen uptake efficiency slope in patients with coronary artery disease. Braz J Med Biol Res. 2016;49(2):e4890. https://doi.org/ 10.1590/1414-431X20154890.

56. Jouven X, Empana JP, Schwartz PJ, Desnos M, Courbon D, Ducimetiere P. Heart-rate profile during exercise as a predictor of sudden death. N Engl J Med. 2005;352(19):1951-8. https:// doi.org/10.1056/NEJMoa043012.

57. Khan MN, Pothier CE, Lauer MS. Chronotropic incompetence as a predictor of death among patients with normal electrograms taking beta blockers (metoprolol or atenolol). Am J Cardiol. 2005;96(9):1328-33. https://doi.org/10.1016/j.amjcard.2005.06.082.

58. Lauer MS, Mehta R, Pashkow FJ, Okin PM, Lee K, Marwick TH. Association of chronotropic incompetence with echocardiographic ischemia and prognosis. J Am Coll Cardiol. 1998;32(5):1280 6. https://doi.org/10.1016/s0735-1097(98)00377-5.

59. Nishime EO, Cole CR, Blackstone EH, Pashkow FJ, Lauer MS. Heart rate recovery and treadmill exercise score as predictors of mortality in patients referred for exercise ECG. JAMA. 2000;284(11):1392-8. https://doi.org/10.1001/jama.284.11.1392.

60. Cole CR, Blackstone EH, Pashkow FJ, Snader CE, Lauer MS. Heart-rate recovery immediately after exercise as a predictor of mortality. N Engl J Med. 1999;341(18):1351-7. https://doi.org/10. 1056/NEJM199910283411804. 
61. Morshedi-Meibodi A, Larson MG, Levy D, O'Donnell CJ, Vasan RS. Heart rate recovery after treadmill exercise testing and risk of cardiovascular disease events (the Framingham heart study). Am J Cardiol. 2002;90(8):848-52. https://doi.org/10.1016/s00029149(02)02706-6.

62. Aune D, Sen A, o'Hartaigh B, Janszky I, Romundstad PR, Tonstad $\mathrm{S}$, et al. Resting heart rate and the risk of cardiovascular disease, total cancer, and all-cause mortality - a systematic review and dose-response meta-analysis of prospective studies. Nutr Metab Cardiovasc Dis. 2017;27(6):504-17. https://doi.org/10.1016/j. numecd.2017.04.004.

63. Abbott TE, Ackland GL, Archbold RA, Wragg A, Kam E, Ahmad $\mathrm{T}$, et al. Preoperative heart rate and myocardial injury after noncardiac surgery: results of a predefined secondary analysis of the VISION study. Br J Anaesth. 2016;117(2):172-81. https://doi.org/ 10.1093/bja/aew182.

64. Whittle J, Nelson A, Otto JM, Stephens RC, Martin DS, Sneyd JR, et al. Sympathetic autonomic dysfunction and impaired cardiovascular performance in higher risk surgical patients: implications for perioperative sympatholysis. Open Heart. 2015;2(1):e000268. https://doi.org/10.1136/openhrt-2015-000268.

65. Abbott TEF, Pearse RM, Beattie WS, Phull M, Beilstein C, Raj A, et al. Chronotropic incompetence and myocardial injury after noncardiac surgery: planned secondary analysis of a prospective observational international cohort study. Br J Anaesth. 2019;123(1): 17-26. https://doi.org/10.1016/j.bja.2019.03.022.

66. Abbott TEF, Pearse RM, Cuthbertson BH, Wijeysundera DN, Ackland GL. Investigators Ms. cardiac vagal dysfunction and myocardial injury after non-cardiac surgery: a planned secondary analysis of the measurement of exercise tolerance before surgery study. Br J Anaesth. 2019;122(2):188-97. https://doi.org/10.1016/ j.bja.2018.10.060.

67. Ackland GL, TEF A, Minto G, Clark M, Owen T, Prabhu P, et al. Heart rate recovery and morbidity after noncardiac surgery: Planned secondary analysis of two prospective, multi-centre, blinded observational studies. PLoS One. 2019;14(8):e0221277. https://doi.org/10.1371/journal.pone.0221277 Study highlighting that postoperative all-cause morbidity is more common in patients with impaired heart rate recovery identified by CPET.

68. Moonesinghe SR, Harris S, Mythen MG, Rowan KM, Haddad FS, Emberton M, et al. Survival after postoperative morbidity: a longitudinal observational cohort study. Br J Anaesth. 2014;113(6):977-84. https://doi.org/10.1093/bja/aeu224.

69. Zweerink A, van der Lingen ACJ, Handoko ML, van Rossum AC, Allaart CP. Chronotropic incompetence in chronic heart failure. Circ Heart Fail. 2018;11(8):e004969. https://doi.org/10.1161/ CIRCHEARTFAILURE.118.004969.

70. Brubaker PH, Kitzman DW. Chronotropic incompetence: causes, consequences, and management. Circulation. 2011;123(9):101020. https://doi.org/10.1161/CIRCULATIONAHA.110.940577.

71. Elhendy A, Mahoney DW, Khandheria BK, Burger K, Pellikka PA. Prognostic significance of impairment of heart rate response to exercise: impact of left ventricular function and myocardial ischemia. J Am Coll Cardiol. 2003;42(5):823-30. https://doi.org/ 10.1016/s0735-1097(03)00832-5.

72. Savonen KP, Kiviniemi V, Laukkanen JA, Lakka TA, Rauramaa TH, Salonen JT, et al. Chronotropic incompetence and mortality in middle-aged men with known or suspected coronary heart disease. Eur Heart J. 2008;29(15):1896-902. https://doi.org/10.1093/ eurheartj/ehn269.

73. Myers J, Tan SY, Abella J, Aleti V, Froelicher VF. Comparison of the chronotropic response to exercise and heart rate recovery in predicting cardiovascular mortality. Eur J Cardiovasc Prev Rehabil. 2007;14(2):215-21. https://doi.org/10.1097/HJR. 0b013e328088cb92.
74. Laforgia P, Bandera F, Alfonzetti E, Guazzi M. Exercise chronotropic incompetence phenotypes the level of cardiovascular risk and exercise gas exchange impairment in the general population. An analysis of the euro-EX prevention trial. Eur J Prev Cardiol. 2019;2047487319863506. https://doi.org/10.1177/ 2047487319863506.

75. Brubaker PH, Kitzman DW. Prevalence and management of chronotropic incompetence in heart failure. Curr Cardiol Rep. 2007;9(3):229-35.

76. Al-Najjar Y, Witte KK, Clark AL. Chronotropic incompetence and survival in chronic heart failure. Int J Cardiol. 2012;157(1):48-52. https://doi.org/10.1016/j.ijcard.2010.11.018.

77. Magri D, Corra U, Di Lenarda A, Cattadori G, Maruotti A, Iorio A, et al. Cardiovascular mortality and chronotropic incompetence in systolic heart failure: the importance of a reappraisal of current cut-off criteria. Eur J Heart Fail. 2014;16(2):201-9. https://doi.org/ 10.1002/ejhf.36.

78. Lauer MS, Francis GS, Okin PM, Pashkow FJ, Snader CE, Marwick TH. Impaired chronotropic response to exercise stress testing as a predictor of mortality. JAMA. 1999;281(6):524-9. https://doi.org/10.1001/jama.281.6.524.

79. Ackland GL, Whittle J, Toner A, Machhada A, Del Arroyo AG, Sciuso A, et al. Molecular mechanisms linking autonomic dysfunction and impaired cardiac contractility in critical illness. Crit Care Med. 2016;44(8):e614-24. https://doi.org/10.1097/CCM. 0000000000001606.

80. Abbott TEF, Minto G, Lee AM, Pearse RM, Ackland GL, Pom-Hr P$\mathrm{O}$, et al. Elevated preoperative heart rate is associated with cardiopulmonary and autonomic impairment in high-risk surgical patients. Br J Anaesth. 2017;119(1):87-94. https://doi.org/10.1093/bja/aex164.

81. Buchfuhrer MJ, Hansen JE, Robinson TE, Sue DY, Wasserman K, Whipp BJ. Optimizing the exercise protocol for cardiopulmonary assessment. J Appl Physiol Respir Environ Exerc Physiol. 1983;55(5): 1558-64. https://doi.org/10.1152/jappl.1983.55.5.1558.

82. Puente-Maestu L, Palange P, Casaburi R, Laveneziana P, Maltais F, Neder JA, et al. Use of exercise testing in the evaluation of interventional efficacy: an official ERS statement. Eur Respir J. 2016;47(2): 429-60. https://doi.org/10.1183/13993003.00745-2015.

83. Hopker J, Passfield L, Coleman D, Jobson S, Edwards L, Carter $\mathrm{H}$. The effects of training on gross efficiency in cycling: a review. Int J Sports Med. 2009;30(12):845-50. https://doi.org/10.1055/s0029-1237712.

84. Jobson S, Hopker J, Korff T, Passfield L. Gross efficiency and cycling performance: a brief review. J Sci Cycling. 2012;1(1):3-8.

85. Russell AP, Foletta VC, Snow RJ, Wadley GD. Skeletal muscle mitochondria: a major player in exercise, health and disease. Biochim Biophys Acta. 2014;1840(4):1276-84. https://doi.org/ 10.1016/j.bbagen.2013.11.016.

86. Whipp BJ, Wasserman K. Efficiency of muscular work. J Appl Physiol. 1969;26(5):644-8. https://doi.org/10.1152/jappl.1969. 26.5.644.

87. Conley KE, Jubrias SA, Cress ME, Esselman P. Exercise efficiency is reduced by mitochondrial uncoupling in the elderly. Exp Physiol. 2013;98(3):768-77. https://doi.org/10.1113/expphysiol.2012.067314.

88. Coen PM, Jubrias SA, Distefano G, Amati F, Mackey DC, Glynn $\mathrm{NW}$, et al. Skeletal muscle mitochondrial energetics are associated with maximal aerobic capacity and walking speed in older adults. J Gerontol A Biol Sci Med Sci. 2013;68(4):447-55. https://doi. org/10.1093/gerona/gls196.

89. Santanasto AJ, Glynn NW, Jubrias SA, Conley KE, Boudreau RM, Amati F, et al. Skeletal muscle mitochondrial function and fatigability in Older adults. J Gerontol A Biol Sci Med Sci. 2015;70(11):1379-85. https://doi.org/10.1093/gerona/glu134.

90. Conley KE, Esselman PC, Jubrias SA, Cress ME, Inglin B, Mogadam C, et al. Ageing, muscle properties and maximal O(2) 
uptake rate in humans. J Physiol. 2000;526(Pt 1):211-7. https:// doi.org/10.1111/j.1469-7793.2000.00211.x.

91. Holloszy JO. Adaptation of skeletal muscle to endurance exercise. Med Sci Sports. 1975;7(3):155-64.

92. Lundby C, Jacobs RA. Adaptations of skeletal muscle mitochondria to exercise training. Exp Physiol. 2016;101(1):17-22. https:// doi.org/10.1113/EP085319.

93. Burgomaster KA, Hughes SC, Heigenhauser GJ, Bradwell SN, Gibala MJ. Six sessions of sprint interval training increases muscle oxidative potential and cycle endurance capacity in humans. J Appl Physiol (1985). 2005;98(6):1985-90. https://doi.org/10. 1152/japplphysiol.01095.2004.

94. Fritzen AM, Thogersen FB, Thybo K, Vissing CR, Krag TO, Ruiz-Ruiz C, et al. Adaptations in Mitochondrial Enzymatic Activity Occurs Independent of Genomic Dosage in Response to Aerobic Exercise Training and Deconditioning in Human Skeletal Muscle. Cells. 2019;8(3). https://doi.org/10.3390/cells8030237.

95. Larsen FJ, Weitzberg E, Lundberg JO, Ekblom B. Effects of dietary nitrate on oxygen cost during exercise. Acta Physiol (Oxford). 2007;191(1):59-66. https://doi.org/10.1111/j.1748-1716.2007.01713. $\mathrm{x}$.

96. Larsen FJ, Schiffer TA, Borniquel S, Sahlin K, Ekblom B, Lundberg JO, et al. Dietary inorganic nitrate improves mitochondrial efficiency in humans. Cell Metab. 2011;13(2):149-59. https://doi.org/10.1016/j.cmet.2011.01.004.

97. Jones AM. Influence of dietary nitrate on the physiological determinants of exercise performance: a critical review. Appl Physiol Nutr Metab. 2014;39(9):1019-28. https://doi.org/10.1139/apnm-20140036.

98. Hightower CE, Riedel BJ, Feig BW, Morris GS, Ensor JE, Woodruff $\mathrm{VD}$, et al. A pilot study evaluating predictors of postoperative outcomes after major abdominal surgery: physiological capacity compared with the ASA physical status classification system. Brit $\mathrm{J}$ Anaesth. 2010;104(4):465-71. https://doi.org/10.1093/bja/aeq034.

99. Colson M, Baglin J, Bolsin S, Grocott MPW. Cardiopulmonary exercise testing predicts $5 \mathrm{yr}$ survival after major surgery. Br J Anaesth. 2012;109(5):735-41. https://doi.org/10.1093/bja/ aes 263 .

100. James S, Jhanji S, Smith A, O'Brien G, Fitzgibbon M, Pearse RM. Comparison of the prognostic accuracy of scoring systems, cardiopulmonary exercise testing, and plasma biomarkers: a singleCentre observational pilot study. Brit J Anaesth. 2014;112(3):4917. https://doi.org/10.1093/bja/aet346.

101. Lai CW, Minto G, Challand CP, Hosie KB, Sneyd JR, Creanor S, et al. Patients' inability to perform a preoperative cardiopulmonary exercise test or demonstrate an anaerobic threshold is associated with inferior outcomes after major colorectal surgery. Brit $\mathrm{J}$ Anaesth. 2013;111(4):607-11. https://doi.org/10.1093/bja/aet193.

102. Nugent AM, Riley M, Megarry J, O'Reilly MJG, MacMahon J, Lowry R. Cardiopulmonary exercise testing in the pre-operative assessment of patients for repair of abdominal aortic aneurysm. Irish J Med Sci. 1998;167(4):238-41. https://doi.org/10.1007/Bf02937421.

103. Thompson AR, Peters N, Lovegrove RE, Ledwidge S, Kitching A, Magee TR, et al. Cardiopulmonary exercise testing provides a predictive tool for early and late outcomes in abdominal aortic aneurysm patients. Ann R Coll Surg Engl. 2011;93(6):474-81. https://oi.org/10.1308/003588411X587235.

104. Hartley RA, Pichel AC, Grant SW, Hickey GL, Lancaster PS, Wisely NA, et al. Preoperative cardiopulmonary exercise testing and risk of early mortality following abdominal aortic aneurysm repair. Br J Surg. 2012;99(11):1539-46. https://doi.org/10.1002/bjs.8896.

105. Prentis JM, Trenell MI, Jones DJ, Lees T, Clarke M, Snowden CP. Submaximal exercise testing predicts perioperative hospitalization after aortic aneurysm repair. J Vasc Surg. 2012;56(6):1564-70. https://doi.org/10.1016/j.jvs.2012.05.097.
106. Goodyear SJ, Yow H, Saedon M, Shakespeare J, Hill CE, Watson $\mathrm{D}$, et al. Risk stratification by pre-operative cardiopulmonary exercise testing improves outcomes following elective abdominal aortic aneurysm surgery: a cohort study. Perioper Med (Lond). 2013;2(1):10. https://doi.org/10.1186/2047-0525-2-10.

107. Rose GA, Davies RG, Appadurai IR, Lewis WG, Cho JS, Lewis $\mathrm{MH}$, et al. Cardiorespiratory fitness is impaired and predicts midterm postoperative survival in patients with abdominal aortic aneurysm disease. Exp Physiol. 2018;103(11):1505-12. https://doi. org/10.1113/EP087092.

108. Epstein SK, Freeman RB, Khayat A, Unterborn JN, Pratt DS, Kaplan MM. Aerobic capacity is associated with 100-day outcome after hepatic transplantation. Liver Transpl. 2004;10(3): 418-24. https://doi.org/10.1002/lt.20088.

109. Ausania F, Vallance AE, Manas DM, Prentis JM, Snowden CP, White SA, et al. Double bypass for inoperable pancreatic malignancy at laparotomy: postoperative complications and long-term outcome. Ann R Coll Surg Engl. 2012;94(8):563-8. https://doi. org/10.1308/003588412X13373405386934.

110. Junejo MA, Mason JM, Sheen AJ, Moore J, Foster P, Atkinson D, et al. Cardiopulmonary exercise testing for preoperative risk assessment before hepatic resection. Br J Surg. 2012;99(8):1097104. https://doi.org/10.1002/bjs.8773.

111. Prentis JM, Manas DM, Trenell MI, Hudson M, Jones DJ, Snowden CP. Submaximal cardiopulmonary exercise testing predicts 90-day survival after liver transplantation. Liver Transpl. 2012;18(2):152-9. https://doi.org/10.1002/lt.22426.

112. Chandrabalan VV, McMillan DC, Carter R, Kinsella J, McKay CJ, Carter CR, et al. Pre-operative cardiopulmonary exercise testing predicts adverse post-operative events and non-progression to adjuvant therapy after major pancreatic surgery. HPB (Oxford). 2013;15(11):899-907. https://doi.org/10.1111/hpb.12060.

113. Kaibori M, Ishizaki M, Matsui K, Nakatake R, Sakaguchi T, Habu $\mathrm{D}$, et al. Assessment of preoperative exercise capacity in hepatocellular carcinoma patients with chronic liver injury undergoing hepatectomy. BMC Gastroenterol. 2013;13:119. https://oi.org/ 10.1186/1471-230X-13-119.

114. Bernal W, Martin-Mateos R, Lipcsey M, Tallis C, Woodsford K, McPhail MJ, et al. Aerobic capacity during cardiopulmonary exercise testing and survival with and without liver transplantation for patients with chronic liver disease. Liver Transpl. 2014;20(1): 54-62. https://doi.org/10.1002/lt.23766.

115. Dunne DF, Jones RP, Lythgoe DT, Pilkington FJ, Palmer DH, Malik HZ, et al. Cardiopulmonary exercise testing before liver surgery. J Surg Oncol. 2014;110(4):439-44. https://doi.org/10. $1002 /$ jso. 23670 .

116. Junejo MA, Mason JM, Sheen AJ, Bryan A, Moore J, Foster P, et al. Cardiopulmonary exercise testing for preoperative risk assessment before pancreaticoduodenectomy for cancer. Ann Surg Oncol. 2014;21(6):1929-36. https://doi.org/10.1245/s10434-014-3493-0.

117. Hennis PJ, Meale PM, Hurst RA, O'Doherty AF, Otto J, Kuper M, et al. Cardiopulmonary exercise testing predicts postoperative outcome in patients undergoing gastric bypass surgery. Br J Anaesth. 2012;109(4):566-71. https://doi.org/10.1093/bja/aes225.

118. Moyes LH, McCaffer CJ, Carter RC, Fullarton GM, Mackay CK, Forshaw MJ. Cardiopulmonary exercise testing as a predictor of complications in oesophagogastric cancer surgery. Ann R Coll Surg Engl. 2013;95(2):125-30. https://doi.org/10.1308/ 003588413 X13511609954897.

119. Ulubay G, Ulasli S, Kupeli E, Yilmaz E, Sezgin A, Haberal M. Value of exercise testing to estimate post-operative complications and mortality in solid organ recipients: a preliminary study. Ann Transplant. 2010;15(2):11-20.

120. Ting SM, Iqbal H, Kanji H, Hamborg T, Aldridge N, Krishnan N, et al. Functional cardiovascular reserve predicts survival pre- 